\title{
The Potential Role and Possible Immunological Mechanisms of Zinc Adjunctive Therapy for Severe Pneumonia in Children
}

\author{
Pa Tamba Ngom ${ }^{*}$, Stephen Howie ${ }^{2}$, Martin O. Ota ${ }^{2}$ and Andrew M. Prentice ${ }^{1}$ \\ ${ }^{I}$ MRC Laboratories, Atlantic Boulevard, Fajara, P.O. Box 273 Banjul, The Gambia \\ ${ }^{2}$ London School of Hygiene and Tropical Medicine, London UK and MRC Keneba, The Gambia
}

\begin{abstract}
Zinc deficiency is widespread and tends to mirror the distribution of infectious diseases prevalent in the developing world. Despite numerous observational studies suggesting a key role for zinc in human immunity and an involvement in disease pathogenesis, the underlying mechanisms remain poorly understood, and zinc intervention trials across a range of diseases have yielded mixed results. There is suggestive evidence that zinc supplementation may reduce initial susceptibility to pneumonia (i.e. preventive), but interpretation is confounded by the use of varied and imprecise diagnostic criteria. Evidence for a therapeutic (i.e. lower pneumonia severity and duration) effect of adjunctive zinc in preexisting disease is less secure and similarly confounded. In neither case has there been substantive research into the putative mechanisms by which zinc could be beneficial.

Animal studies suggest a beneficial role for zinc in T cell immunity; with deficiency resulting in involution of the thymus, which is the seat of $\mathrm{T}$ cell development. Here we review the evidence that zinc may play a critical role in human infectious diseases immunity through effects on $\mathrm{T}$ cell generation and mediation of cytokine production. Additional mechanisms may involve a role in the removal of metabolic toxins via free radical scavenger molecules for which zinc is an essential cofactor. We review the theory and existing evidence to support that zinc supplementation promotes the induction of $\mathrm{T}$ cell immunity to control infection and ameliorate immunopathology including excess inflammation. This is a potential route by which respiratory tissue regeneration may be achieved following respiratory tract infections in children benefiting from zinc adjunct therapy.
\end{abstract}

Keywords: Zinc, pneumonia, T cells, thymus, immunity.

\section{INTRODUCTION}

Pneumonia continues to be the biggest single cause of childhood death, accounting for approximately $20 \%$ of the 10 million annual deaths globally [1] with most in the WHO Africa region. Malnutrition is estimated to contribute up to half of pneumonia deaths [2]. While much emphasis is placed on protein-energy status and vitamin A, it has been proposed that zinc has a real potential in the prevention of pneumonia morbidity and mortality [3, 4]. The etiologic agents for pneumonia, include Streptococcus pneumoniae, Haemophilus influenzae, Respiratory Syncytial Virus (RSV) and a range of other bacteria and viruses [1, 2, 4-10] which suggests that both intra and extra cellular immune responses are important.

Zinc is abundant in all cells of the human body [11], and it plays a crucial role in numerous body functions [12]. Zinc is a vital component of numerous enzymes and is a cofactor in signalling pathways involving zinc requiring proteins [13, 14] as well as driving transcription factor activation and expression [15]. The role of zinc in immunity also involves $\mathrm{T}$ cell independent aspects of the immune system including natural killer (NK) as well as B cells [16]. On the other hand there are limited data regarding $\mathrm{T}$ cell immunity to

*Address correspondence to this author at the MRC Laboratories, Atlantic Boulevard, Fajara, P.O.Box 273 Banjul, The Gambia; Tel: +220 4495442; Fax: +220 4495919; E-mail: tngom@mrc.gm pneumonia. While cells of the innate immune system including macrophages may be important in immunity to pneumonia, unlike $\mathrm{T}$ cells, those lack the ability for memory recall. It has been shown in mice that zinc depletion does not have detectable effects on the antipneumoccocal $\operatorname{IgM}$ responses following immunisation with $\mathrm{T}$ cell independent polysaccharide vaccines [17]. In contrast, zinc deficiency in mice was associated with reduced immune response, a more severe infection and increased risk of death following the administration of a $\mathrm{T}$ cell dependent pneumococcal surface protein A vaccine [18]. This review concentrates on: 1) the potential role of zinc in thymic and $\mathrm{T}$ cell immune activity, and on its possible effects in mediating oxidative stress as well as inflammatory and regulatory cytokines; and 2) the evidence in support of an immune modulating potential for zinc supplementation as adjunctive therapy for reducing pneumonia-associated morbidity and mortality in children from developing countries.

\section{ZINC INTAKE, METABOLISM AND HOMEOSTASIS}

Animal products and sea foods constitute the richest sources of dietary zinc [19], but are expensive and inaccessible for many of the world's poorest populations, making zinc deficiency a particularly widespread disorder in Asia and Africa [20].

Dietary zinc is absorbed across the basolateral membrane of enterocytes in the duodenum and proximal jejunum, mediated by transporters including zinc transport protein-1 
(ZnTP-1), and passes through the portal circulation into the peripheral tissues via the liver [21]. Over $60 \%$ of total body zinc is in skeletal muscle, with approximately $20 \%$ in bone. Marrow, liver, lung and skin, being sites of rapid cell turnover, account for approximately $10 \%$ of the remaining body zinc. Hair also has a relatively high concentration of zinc, while the prostate gland and semen have particularly high concentrations. In humans, requirements for zinc change according to the individual's physiological state. Pregnancy, for example, sets an additional need equivalent to $5-7 \%$ of whole body zinc of non-pregnant women [22].

In humans zinc is obtained only through the diet, and total body zinc status is influenced by: 1) rates of absorption; 2) excretion and losses; and 3) physiological and disease states. The balance in body zinc concentration is maintained by homeostatic mechanisms. Extra cellular (plasma) zinc is labile and turns over rapidly in response to intracellular and tissue zinc utilisation [23]. Zinc absorption and excretion are driven by zinc transporters, with transmembrane domains encoded by 2 solute-linked carrier gene families, Zip and ZnT [24] which drive cellular zinc influx and efflux respectively. Physiological responses, including the acute phase reaction to stressors such as infection, may modulate zinc turnover through zinc binding or release by metalloproteins, the most potent of which are the metallothionein family [25]. Seventy percent of extracellular zinc is transported around the body bound to albumin in the plasma; consequently, hypoalbuminemia accompanying protein-energy malnutrition and aging lowers plasma zinc concentrations. However, only $0.1 \%$ of body zinc is contained in plasma. Plasma zinc has a rapid turnover (150 times a day) to meet the needs of the tissues and is affected by recent dietary intake, therefore, plasma zinc is an unreliable measure of zinc status [26].

Although plasma zinc levels may be lowered in infection as part of the acute phase response, there are suggestions that this is true only in severe infection, perhaps when cytokines, the mediators of the acute phase response, reach a certain threshold, and in adults but not in community studies of children in whom severe infections may not be widespread $[25,27]$. This suggestion is consistent with reports that although children with infections had lower mean plasma zinc concentrations, infection was not predictive of the proportion of children with lower than normal zinc status [28]. Other studies showed no relationship between infection and plasma zinc concentrations [28-30]. In spite of these uncertainties and the known inadequacy of plasma zinc as a marker of zinc status it remains the most widely used index. However, novel approaches including the use of metallothionein gene expression analysis hold potential for true reflection of body zinc status [31].

\section{HUMAN ZINC DEFICIENCY}

Recent estimates are that almost half a million deaths of children under 5 years of age (4-5\% of childhood deaths) may be attributable, in part, to zinc deficiency [32]. As a Type II micronutrient according to Golden's classification $[33,34]$, when threatened by low intakes the body inhibits growth in order to conserve zinc thus making marginal deficiency almost impossible to detect except by growth failure. As a result of these limitations the prevalence of zinc deficiency has to be imputed from responses to randomised intervention trials, meta-analyses of the effects of zinc supplementation on growth, and assessments of dietary zinc supply (http://www.izincg.org).

Due to the high phytate (inositol hexaphosphate) content of plants, which forms a highly insoluble complex with zinc, the bioavailability of zinc from vegetable sources is low. Although cooking and baking reduces the inhibitory effects of phytate and fibre on zinc absorption, consumption of vegetable-based diets remain a risk factor for zinc deficiency. Based on the bioavailability of dietary zinc and childhood growth stunting, WHO $[35,36]$ has estimated that most of sub-Saharan Africa, the Middle East, India and parts of South America are at high risk of zinc deficiency. The International Zinc Nutrition Consultative Group (IZiNCG) estimated that in these populations up to $25 \%$ are at risk of zinc deficiency [20]. In zinc deficiency states and for those most at risk, zinc supplementation is a potentially important way of overcoming dietary insufficiency.

\section{ZINC SUPPLEMENTATION AND CHILDHOOD PNEUMONIA}

Pneumonia is a major killer, responsible for an estimated $19-29 \%$ of the 10 million deaths in children under the age of 5 years worldwide [5, 37]. Consequently, death from pneumonia is the leading single contributor to under-5 mortality globally, which presents a major challenge for the achievement of the fourth Millennium Development Goal to reduce under-5 mortality two-thirds by 2015 [38]. Two distinctive potential roles for zinc in modulating pneumonia burden exist; firstly as a preventive element when administered prior to pneumonia disease; secondly, zinc may change the course of prexisting pneumonia when added as an adjunct to conventional antibiotic treatment potentially to reduce the severity and duration of pneumonia in sufferers. There are mixed reports regarding the benefits of zinc supplementation; for example a relatively small RCT on Guatemalan children reported no benefit on the incidence or prevalence of respiratory illness from zinc supplementation [39]. More recent reports combining zinc with iron or vitamin A also reported no benefits [40, 41]. However, the overall evidence including pooled and meta-analyses appears to be consistent with zinc supplementation being beneficial for the prevention of pneumonia disease in those under the age of 5 (pooled and meta-analyses are summarised in Table 1). One such study in Mexican preschool children 18-36 months old, using zinc methionine, thought to reduce phytate binding, in combination with iron or zinc on its own, reported reduced respiratory illness with zinc administration [39, 42]. That study reported increased plasma zinc after supplementation. In another study, Sazawal et al. showed a $45 \%$ reduced incidence of acute lower respiratory tract infection, predominantly pneumonia, in a cohort of 609 Indian children given $10 \mathrm{mg}$ zinc/day for 6 months [43]. A single weekly dose of zinc supplementation (70mg zinc/week) given to 809 healthy Bangladeshi children aged 60 days to 12 months significantly reduced the incidence of pneumonia with a relative risk of 0.83 (95\% CI 0.73-0.95) for all cause mortality; with 2 and 14 deaths in the zinc and placebo groups respectively, and with no pneumonia-related deaths in the zinc group compared to 10 in the placebo group [44]. A large study $(n=2482)$ of $6-30$ 
Table 1. Prevention of Pneumonia: Pooled and Meta-Analyses of RCTs for Pneumonia or LRTI

\begin{tabular}{|c|c|c|c|c|c|c|}
\hline \multirow{2}{*}{$\begin{array}{l}\text { Year and } \\
\text { Origin }\end{array}$} & \multirow{2}{*}{$\begin{array}{l}\text { Authors } \\
\text { (Journal) }\end{array}$} & \multicolumn{2}{|c|}{ Subjects } & \multirow{2}{*}{$\begin{array}{l}\text { Zinc } \\
\text { Dose } \\
\text { (mg) }\end{array}$} & \multirow{2}{*}{$\begin{array}{c}\text { Criteria for } \\
\text { Inclusion of Studies }\end{array}$} & \multirow{2}{*}{$\begin{array}{c}\text { Main Effects of } \\
\text { Zinc Supplementation }\end{array}$} \\
\hline & & $\begin{array}{l}\text { No. of Trials } \\
\text { and Duration }\end{array}$ & $\begin{array}{l}\text { Age } \\
(\mathbf{m})\end{array}$ & & & \\
\hline $\begin{array}{c}1999 \\
\text { (Pooled Analysis) }\end{array}$ & $\begin{array}{l}\text { Bhutta, } \text { et al. } \\
\text { (J Pediatr.) }\end{array}$ & $\begin{array}{l}5-\mathrm{RCTs} \\
2 \mathrm{w}-46 \mathrm{k}\end{array}$ & 3-36 & $5-20 / \mathrm{d}$ & $\begin{array}{c}\text { Zinc for } \geq 2 \text { weeks and other nutrients. } \\
\text { Pneumonia out-come. }\end{array}$ & $\begin{array}{c}\text { Overall reduction for pneumonia } \\
\text { incidence. Continuous supplements } \\
\text { OR }=0.59 \text { (95\% CI } 0.41 \text { to } 0.83 \text { ); } \\
\text { Short-course supplements } \\
\text { OR }=0.74 \text { (95\%CI } 0.4 \text { to } 1.37)\end{array}$ \\
\hline $\begin{array}{c}2007 \\
\text { (Meta Analysis) }\end{array}$ & $\begin{array}{l}\text { Aggarwal, et al. } \\
\text { (Pediatr.) }\end{array}$ & $\begin{array}{l}12 \mathrm{RCT} \\
\geq 3 \mathrm{~m} \\
\text { Long }\end{array}$ & $<60$ & $\begin{array}{l}5-70 \\
\text { Daily-twice } \\
\text { Weekly }\end{array}$ & $\begin{array}{l}\text { Studies using zinc, Vitamin A, } \\
\text { iron, or other. LRTI out-come. }\end{array}$ & $\begin{array}{l}\text { Zinc supplementation } \\
\text { significantly reduced } \\
\text { frequency and severity } \\
\text { of respiratory illness. }\end{array}$ \\
\hline $\begin{array}{c}2010 \\
\text { (Meta Analysis) }\end{array}$ & $\begin{array}{l}\text { Mathew, et al. } \\
\text { (Indian Pediatrics) }\end{array}$ & $\begin{array}{l}11 \mathrm{RCT} \\
4-10.8 \mathrm{~m}\end{array}$ & $1-180$ & $5-20 / \mathrm{d}$ & $\begin{array}{l}\text { Zinc only supplement } \\
\text { and pneumonia out-come. }\end{array}$ & $\begin{array}{c}\text { Zinc does not prevent ( } 8 \text { trials), } \\
\text { Decreases ( } 2 \text { trials), increases ( } 1 \text { trial) } \\
\text { pneumonia occurrence. }\end{array}$ \\
\hline
\end{tabular}

month old slum dwellers in New Delhi receiving daily zinc (10mg and 20mg/day for infants and older children respectively) and vitamin $\mathrm{A}$, reported significantly reduced incidence (absolute risk reduction $2.5 \%$, 95\% CI $0.4-4.6 \%$ ) of pneumonia [45]. Pooled analyses of these and other randomised controlled trials (RCTs) for the prevention of pneumonia [46] and more recently, meta-analyses of a total of 17 pneumonia prevention RCTs [47] both concluded that zinc supplementation significantly reduced pneumonia disease incidence and severity in children under the age of 5 years. The difficult issue of heterogeneity of studies included in meta-analysis is further illustrated in the latest systemic review of all studies to date, which used only zinc and pneumonia-only as an outcome [48].

In addition to the pneumonia disease prevention and mortality reductions described above, others have looked at the effects of zinc supplementation on treatment of severe pneumonia disease (summarised in Table 2). The comparability of such studies is made more difficult by the use of different clinical definitions for pneumonia but nevertheless it is worthwhile attempting to draw broad inferences. One study in Bangladesh on 270 children aged 223 months with severe pneumonia who were given zinc supplementation at $20 \mathrm{mg}$ zinc/day, reduced the duration of disease from 5 to 4 days with a relative hazard for duration of severe pneumonia (assessed by shorter duration of chest in-drawing, respiratory rate $>50 /$ minute and hypoxia) of 0.7 (95\% CI 0.51-0.98) [49]. That study showed an increase in serum zinc levels from $10.1 \mu \mathrm{mol} / \mathrm{L}$ to $14.5 \mu \mathrm{mol} / \mathrm{L}$ $(\mathrm{p}<0.0001)$ following supplementation which is consistent with initial zinc deficiency. A small study

by Bhutta et al. on Indian children 9-180 months [50], reported similar improvements in serum zinc levels in each group after 5 days of treatment with $40 \mathrm{mg} /$ day zinc or placebo, but showed no effects on pneumonia outcome; although the authors speculated that the subjects may not have been truly zinc deficient. Another study, Bose et al. reported no benefit for zinc adjunct therapy in 2-23 month old Indian children even though plasma zinc levels were improved by supplementation [51]. The high frequency of wheeze in that study suggests that viral bronchiolitis, a typically less serious condition than bacterial pneumonia but included within the WHO pneumonia definition, was a confounding factor. Similar arguments could be made of the latest study of 1-23 month old Indian children Valentiner Branth et al. reported no benefits for zinc adjunct therapy in a group of children diagnosed with severe pneumonia accompanied by $80-90 \%$ wheeze [52]. Those authors acknowledged that their diagnoses of severe pneumonia may not be specific enough. The possibility that zinc adjunct therapy might be of greater benefit in bacterial pneumonia than viral bronchiolitis is supported by evidence of a stronger association between zinc supplementation and recovery in subjects without wheeze in the trial of Brooks and colleagues [49]. In another study of $<11$ year old Australian children, Chang et al. using vitamin A and zinc reported no benefits from either zinc on its own or in combination with vitamin A [53] and they discussed that baseline zinc levels were within the normal range and reported a 2.5 fold higher risk of readmission in the zinc than placebo group after 120 days follow up. That study also included children over twice the 5 year average of most studies. Mathew [48] used a systematic review of the studies listed in Table $\mathbf{2}$ and concluded that although the data was not suitable for meta-analysis, the balance of evidence points to no therapeutic benefit for zinc in pneumonia. However, the variety of definitions used for pneumonia was a weakness. These conflicting reports indicate that the completion of further trials must be awaited before firmer conclusions on the role of zinc adjunct therapy in pneumonia can be made

Any benefits of zinc supplementation are expected to include mortality reduction. However, despite the evidence in favour of zinc supplementation for the prevention of severe pneumonia, two recent large scale trials of zinc supplementation $[54,55]$, reported that zinc does not benefit overall mortality in children. One of those studies, in Nepal [54] reported that those older than 12 months and boys, were at lower relative risk of death if they received zinc $\mathrm{RR}=0.82$ (95\% CI=0.68-1.00; p=0.045) and 0.81 (95\% CI 0.66-0.99; $\mathrm{p}=0.04)$ respectively. Boys older than 12 months were at an even lower risk of death if they received zinc (relative risk = $0.71(95 \% \mathrm{CI}=0.54-0.93 ; \mathrm{p}=0.013)$. Similar, but nonstatistically significant trends for lower risk of mortality with zinc supplementation were also reported in a very similar study conducted in Pemba Island, Zanzibar [55]. These 
Table 2. Treatment of Pneumonia: RCTs of Zinc Supplementation on Pneumonia and Respiratory Illness

\begin{tabular}{|c|c|c|c|c|c|}
\hline 2004 (Bangladesh) & Brooks, et al. (Lancet) & 270 & $2-23$ & $\begin{array}{l}20 / \mathrm{d} \\
\text { until discharge }\end{array}$ & $\begin{array}{l}\text { Reduced duration of severe pneumonia. } \\
\qquad \text { RH=0.70 (95\%CI: } 0.51-0.98) \text {. }\end{array}$ \\
\hline 2006 (Australia) & Chang, et al. (MJA) & 187 & $<132$ & $\begin{array}{l}20(<12 \mathrm{~m}) \\
40(>12 \mathrm{~m})\end{array}$ & $\begin{array}{l}\text { No clinical benefit. Increased morbidity and } \\
\text { ALRI readmission (RR, 2.4; 95\%CI, 1.0-6.1). }\end{array}$ \\
\hline 2010 (Nepal) & Valentiner-Branth (AJCN) & 2628 & $2-35$ & $10 / 20 \mathrm{mg} / \mathrm{d}$ & $\begin{array}{l}\text { No significant differences, but } 84-89 \% \\
\text { wheeze in severe pneumonia group. }\end{array}$ \\
\hline
\end{tabular}

studies suggest that boys, but not girls and children older than 12 months may differentially benefit when given zinc $[55,56]$. The authors argue that this was because boys have a higher requirement for zinc than girls. However, in the $<12$ months old group, the apparent increased risk of pneumonia and higher mortality in boys than girls, may also account for the speculated benefit of zinc for boys at this age. Furthermore, children older than 12 months may no longer benefit from zinc acquired in utero (consistent with the preferential shunting of zinc across the placenta) [57], and breast milk (considered an adequate source of infant supplies even at suboptimal maternal stores) and this may partly explain the sex and age differences. They also suggest that the absence of significant differences in mortality of the infants may be related to the lower zinc dose of $5 \mathrm{mg}$ given [55]. Finally, the authors point out that the effects of vitamin A, which was administered to both the zinc and placebo group may obscure any mortality differences seen.

Although these two large studies were limited by factors including the small dose of zinc and the endemicity of infections (e.g. malaria), there are further reports showing no benefit for zinc in reducing all cause mortality [40,58]. It is possible that interactions between coexisting infections may result in a new outcome, which requires further investigation. However, findings showing that zinc supplementation has the potential to improve childhood morbidity and mortality also exist [44, 49, 59]. In 2001, Sazawal et al. showed lower mortality rates in 1154 small for gestational age Indian children given $5 \mathrm{mg}$ zinc daily for 254 days, with a risk ratio of 0.32 (95\% CI: 0.12-0.89); although this was based on a very small number of deaths [59].

Taken together, the evidence suggests that zinc supplementation is most beneficial to pneumonia prevention, with less support for treatment and overall mortality; but stringent case definition for pneumonia as well as controlling for potential confounders including age, sex, coinfection, nutritional status, zinc dose and timing is required [60].

The heterogeneity of existing studies including pneumonia case definition is one weakness of such a review. To fully characterise the potential benefits of zinc on pneumonia, we argue that there is a need to develop possible mechanistic data; for example empirical estimates of activities of immune organs and their products including the thymus and $\mathrm{T}$ cell parameters potentially influenced by zinc.

\section{POTENTIAL BENEFITS OF MECHANISTIC STUDIES FOR ZINC ADJUNCT THERAPY IN CHILDHOOD SEVERE PNEUMONIA}

The purpose of zinc adjunct therapy for severe pneumonia in children is to prevent or control morbidity and mortality due to severe pneumonia. In order to optimise therapeutic protocols, it is important to identify specific measurable outcomes. The characterisation of the possible immunological mechanisms has potential in providing markers to predict: 1) who would most benefit from adjunct zinc therapy; 2) the success, or failure, of adjunct zinc therapy; 3) prognosis and recurrence; and 4) possible longer term risks.

The ways in which zinc influences pneumonia are not understood. Here we discuss plausible mechanisms relating to both pathogen and host in this complex relationship. We propose that the mechanisms by which zinc might influence pneumonia pathology may be related to the effects of zinc on the thymus and $\mathrm{T}$ cell immunity $[61,62]$, thus modulating host immunity to pneumonia. Further possible mechanisms relating to pathogen effects are also reviewed.

\section{THE THYMUS AND $T$ CELLS, POTENTIAL MODULATORS OF THE EFFECTS OF ZINC ON SEVERE PNEUMONIA}

Animal models of zinc deficiency have shown that the thymus is markedly affected, with young mice fed a zincdeficient diet for 28 days rapidly developing thymic involution especially of the cortex [63]. Another study, reported involuted thymi with decreased thymic weight and cellularity, which was accompanied by reduced $\mathrm{T}$ but not $\mathrm{B}$ lymphocyte counts [64]. The reduced $\mathrm{T}$ cell numbers were thought to be due to a $60 \%$ increase in apoptosis of pre-T cells in the zinc deficient compared to the zinc replete controls.

Like protein energy malnutrition (PEM), human zinc deficiency is associated with atrophy of the thymus, lymphopenia and diminished cellular and antibody mediated responses [16]. One study showed a 10 fold reduction in thymic size of malnourished children compared to controls. 
Increased thymic size was seen at 1 and 2 months following nutritional rehabilitation and the administration of an additional $2 \mathrm{mg}$ zinc per day resulted in a further 1.5 fold increased thymus size $[65,66]$. The ontogeny of the human thymus reveals a relative increase for the first year of life and plateaus until early adulthood, and then declines in size [67, 68]. It is interesting that serum zinc levels have been reported to follow a similar pattern in humans [69].

The relationship between thymic size and function is still unclear. However, in Guinea Bissau, two studies associated a larger thymus size at birth with lower infant mortality in a community where infections accounted for most deaths [70]. A smaller thymus was an independent and consistent risk factor for mortality, and a halving of thymus size was associated with a $70 \%$ increased mortality [71]. The authors concluded that thymus size was an important predictor of immune competence.

In a study of 8 malnourished children given zinc, thymic atrophy, judged by radiology, was reversed [72]. In another study using adult human volunteers, where mild zinc deficiency was achieved by putting volunteers on a soyprotein-based diet with $3-5 \mathrm{mg}$ zinc per day for 28 days, followed by a $27 \mathrm{mg}$ zinc per day in addition to the soy protein diet for a further 12 weeks, the activity of thymulin (Glu-Ala-Lys-Ser-Gln-Gly-Gly-Ser-Asn-OH), a hormone produced by thymic epithelial cells [73], was shown to be significantly lower in zinc deficiency, and this was corrected by the addition of zinc [74].

\section{THYMULIN, A POSSIBLE MEDIATOR OF THE IMMUNOLOGICAL MECHANISMS OF ZINC}

Inactive thymulin is secreted by thymic epithelial cells (TECs), and then binds zinc in a 1:1 molar ratio to gain optimum biological activity [75]. In its active form, thymulin binds high affinity receptors on $\mathrm{T}$ cells [76] and induces further $\mathrm{T}$ cell receptor expression, which drives $\mathrm{T}$ cell adhesion, migration and maturation, and promotes $\mathrm{T}$ cell function [77]. In human stem cells, activated thymulin induces the expression of Thy 1 (CD90), found on the surface of precursor stem cells [78]. CD90 in turn interacts with thymic epithelial cells to enable $\mathrm{T}$ cell precursor migration through the various milieu of the thymus, resulting in the commitment to the $\mathrm{T}$ cell lineage leading to their development into mature $T$ cells [79]. Thymulin then continues to exert effects on the differentiation of $\mathrm{T}$ cells in the peripheral circulation. Fig. (1) is a model of how zinc is predicted to influence $\mathrm{T}$ cell development including interactions with thymulin; and how the ensuing immune processes may influence lung pathology during severe pneumonia. Thymulin depends on zinc for its biological activities, which include induction of thymic and $\mathrm{T}$ cell development and anti-inflammatory properties [80]. Consequently thymulin may constitute part of the trigger important for the impact of zinc on $\mathrm{T}$ cell immunity and the predicted effects on severe pneumonia outcome. Raised serum levels of the proinflammatory cytokine, IL-6 found in humans with severe pulmonary hypertension was interpreted as indication that IL-6 was associated with the condition [81]. The association is thought to be related to connective tissue diseases and HIV infection [82]. In rats thymulin decreased monocrotaline-induced pulmonary arterial hypertension by lowering IL-6 driven inflammation [83]. Reduced IL-6 levels were also seen in the lungs in thymulin or zinc administered rats compared to controls [83]. Similarly, thymulin inhibited lung damage in mice administered bleomycin, which is an antitumor drug known to cause interstitial pneumonia by increasing the synthesis of pro-inflammatory cytokines by lymphocytes [84]. Thymulin is also thought to reduce cellular inflammatory effects in an experimental model of lung fibrosis via IL-6 in a similar way [84].

In foetal alveolar epithelial type II cell cultures, it was shown that the combination of thymulin and zinc resulted in a synergistic reduction of proinflammatory cytokine IL1 $\beta$ induced by LPS [85].

There is much speculation that thymulin gene therapy has direct anti-inflammatory roles and synergy between zinc, which lowers TNFo, IL1 $\beta$ and IL6; and thymulin, which lowers IL1 $\beta$ but not TNF $\alpha$ and IL6 [85] may be critical for lung damage during pneumonia. The addition of zinc even to biologically active synthetic thymulin may be beneficial by further lowering inflammation in thymulin gene therapy [86].

\section{ZINC AND S. PNEUMONIAE VIRULENCE FACTORS}

Childhood pneumonia requiring hospitalisation has a significant case fatality rate in developing countries, typically $5-10 \%$ even in referral hospitals. Up to half of pneumonia cases are caused by $S$. pneumoniae, a gram positive bacterium [1]. In addition to the well-studied virulence factors, including the capsular polysaccharide, cell wall and surface proteins [87], S. pneumoniae expresses zinc metalloprotease B (ZmpB) which induces TNF $\alpha$ production in the respiratory tract to promote inflammation. Mice challenged with wild type $S$. pneumonia had more TNF- $\alpha$ mediated inflammation compared to a $\mathrm{ZmpB}$ mutant strain which showed similar morphology, phenotype and autolytic effect to the wild type, indicating a possible role for $\mathrm{ZmpB}$ as a Streptococcus pneumoniae virulence factor mediated by $\mathrm{TNF} \alpha[88,89]$.

Co-culturing human pneumocyte II cell line (A549) with $S$. pneumoniae was reported to induced secretion of the proinflammatory cytokine IL-8 [90]. In addition, the induction of IL-6 during pneumonia is thought to contribute to the lowered blood zinc levels associated with the acute phase reaction during infections [91].

These and similar observations that infective organisms may subvert host micronutrient metabolism may help to resolve a previous therapeutic paradox, namely that if plasma zinc depletion is an intended host defence mechanism then, in theory, it might sometimes be counter-productive to augment zinc intake. However, current evidence suggests that the negative acute phase response may be primarily targeted at depletion of circulating iron and, to date, there appears little if any evidence that therapeutic zinc causes harm. it may sometimes be counter-productive to augment zinc intake. Host defence mechanisms have evolved a relatively limited range of innate and adaptive immune systems which require pluripotent mechanisms against a wide range of possible invasive organisms and will likely have been selected on the basis of their aggregate effect on survival rather than their effectiveness against a single 


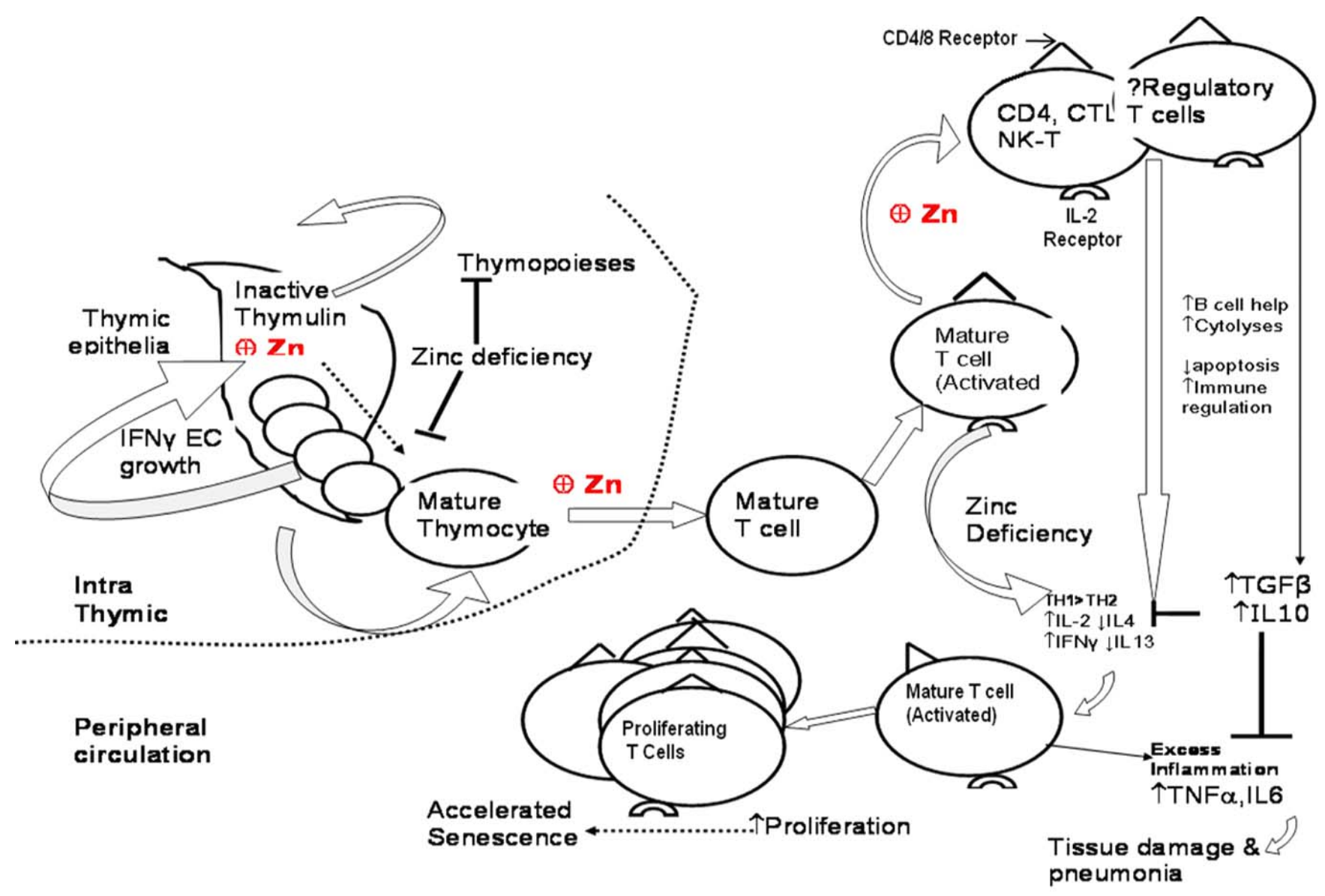

Fig. (1). Proposed model showing the potential role for zinc in thymic and T cell development and pneumonia pathology.

Fig. (1) is a proposed model of how zinc may influence T cell immunity during severe pneumonia to alleviate lung damage. To the left of the dotted line, in the intra-thymic compartment, inactive thymulin generated by thymic epithelia, combines with zinc to result in functional thymulin, which drives thymocyte development in the direction of the broken arrow to export mature $\mathrm{T}$ cells into the peripheral circulation (right part of the dotted line). Zinc deficiency blocks intra thymic $\mathrm{T}$ cell development as shown. In the peripheral circulation zinc has the potential to drive further maturation, activation and differentiation into helper (CD4), effectors and cytotoxic T lymphocytes (CTL) and possibly including naturally occurring regulatory $\mathrm{T}$ cells, which originate from the thymus. Regulatory $\mathrm{T}$ cells may also produce TGF $\beta$ and IL10 to counteract potential immune pathology.

During zinc deficiency in children, a shift from the expected TH2 to a TH1 bias, and a dominant pro-inflammatory cytokine profile which has been reported to exist, has the potential to induce accelerated proliferation (possibly driven by excess TH1 cytokines, including IL-2), which in turn may lead to premature senescence of T cells. Excess inflammation (driven by pro-inflammatory cytokines, including TNF $\alpha$ and IL-6) could contribute to immunopathologic lung damage in severe pneumonia.

A balanced cytokine profile (provided by Tregs for example) may counter disruptions of the TH1/TH2 balance and the effects of proinflammatory cytokines during zinc adequacy, thus dampening/alleviating potential lung injury associated with pneumonia disease.

organism or disease. Targeted therapeutics may be able to improve upon evolutionary mechanisms if we had a better understanding of the complexities at play.

\section{ZINC AND INFECTIOUS DISEASE IMMUNE PATHOLOGY}

Excessive immune reaction mediated by effector cells and the cytokines they secrete, may precipitate immune pathology arising from inflammation-driven tissue damage. The lung is particularly prone to immune pathology [92]. Regulatory $\mathrm{T}$ cells (Tregs) play a critical role in preventing immunopathology resulting from exuberant and excessive inflammatory responses to antigens in the host. However, there are no data regarding the effect of zinc on Tregs and how such effects may mediate the putative effects of zinc on pneumonia. Considering the important role of Tregs in immune pathology [93], knowledge in this area is likely to enhance the understanding of the mechanisms of pneumonia pathogenesis and zinc adjunctive therapy. It is predicted that Treg numbers and function will be lowered by zinc deficiency, considering that the thymus is the source of such 
cells $[94,95]$, and that the thymus is seriously affected by zinc deficiency.

\section{ANTI-INFLAMMATORY AND ANTI-OXIDANT ROLES OF ZINC IN INFECTIOUS DISEASES}

Zinc appears to be a potent immune regulator in that proinflammatory cytokines (TNF, IL6 and IL1) were all lowered by zinc during lipopolysaccharide (LPS) stimulation [91]. It is thought that pro-inflammatory cytokines such as IL-6 which regulate the acute phase reaction at the start of an infection, influence zinc transporter proteins such as Zip14 [91], which in turn modulate zinc homeostasis in mice, for example [96]. One consequence of the acute phase response is enhanced hepatic production of plasma proteins mostly induced by IL-6 [97]. Such proteins alter the systemic distribution of micronutrients such as zinc and iron by preventing their release from storage cells, including macrophages in the case of hepcidin for the regulation of $\mathrm{Fe}$ [98]. Zinc has been shown to inhibit free NFkB translocation to the nucleus, thus preventing the pro-inflammatory cytokine gene expression [99], an inhibition, which when lifted may result in increased IL-2 and TNF $\alpha$ secretion, possibly accompanied by excessive $\mathrm{T}$ cell proliferation and immune pathology. The human leukaemia cell line (HL-60) produced more TNF $\alpha$, IL1 $\beta$ and IL- 8 pro-inflammatory cytokines in conditions of zinc deficiency [100], which is consistent with this hypothesis.

Although zinc may not directly interact with oxidant species, it exerts antioxidant properties indirectly by stabilising otherwise vulnerable cell membranes and being a cofactor of antioxidant enzymes especially super oxide dismutase (SOD) and metalloproteins which are also free radical scavengers [101]. By competing for binding proteins, hence inhibiting iron intake, zinc might also antagonise redox active agents such as iron, which drive $\mathrm{OH}$ formation from $\mathrm{H}_{2} \mathrm{O}_{2}$ [102]. Furthermore, antioxidant effects of zinc have been demonstrated by the decreased levels of indicators of lipid per oxidation (malondialdehyde, HA and 8-hydroxy deoxyguanine) seen in healthy volunteers administered 8 weeks of $45 \mathrm{mg}$ zinc acetate daily compared to a placebo group [103]. In the same zinc recipients, induction of proinflammatory cytokine (TNF $\alpha$ and IL-1 $\beta$ ) mRNA levels in their PBMC stimulated with LPS, was lower compared to the placebo group. [103] In vitro studies using HL-60 showed that zinc exerted its inhibitory effects on pro-inflammatory cytokine mRNA expression through the up-regulation of the transactivating factor A20, which serves as a negative feedback regulator of NFkB activation [103].

Anti-oxidant and anti-inflammatory properties of zinc are potentially important in the pathogenesis of respiratory tract infections where damage to the mucosal membranes and congestion by inflammatory exudates may account for much of the pathophysiology of severe pneumonia [87]. Zinc may lower reactive oxygen species (ROS) accumulation during infection. ROS may cause direct tissue damage directly influence pathogenicity of infectious agents such as $S$. pneumoniae as discussed earlier.

The role of zinc as a growth agent offers regeneration potential for damaged respiratory epithelial cells, a process required for the restoration of damaged lungs following severe pneumonia [104]. In Helicobacter pylori infection, low zinc levels were associated with increased inflammation and gastric mucosa damage [105], which is consistent with the prediction that lung damage in pneumonia may be mediated via lung epithelial tissue damage culminating from low zinc coupled with bacterial infection.

\section{ZINC, LYMPHOCYTE APOPTOSIS AND PNEUMONIA PATHOGENESIS}

As an antioxidant, zinc plays a part in the removal of ROS, which may induce apoptosis of host cells and tissues [106]. ROS are believed to induce cell death through the Fas apoptosis receptor in primary lung epithelial cells by the down regulation of apoptosis inhibitory proteins, an effect which was reversed by the antioxidant scavenging enzymes glutathione peroxidase and SOD, for which zinc is a cofactor [107]. It is possible that in severe pneumonia, the death of respiratory epithelial cells of the lung is associated with increased oxidative stress during this time, which in the absence of zinc is exacerbated. In vitro experiments show that zinc-supplemented $\mathrm{U} 937$ cells are protected from $\mathrm{H}_{2} \mathrm{O}_{2}$ induced apoptosis [108]. In zinc deficient mice, apoptosis as assessed by cell cycle analysis of lymphocyte precursors, resulted in 38\% shrinkage of the thymic pre-T cell compartment, which translated to $80 \%$ reduced thymocytes numbers [109]. In a human submandibular gland cell line, zinc induced the expression of the anti-apoptotic gene, Bcl-2 and countered apoptosis [110]. Research suggests that the anti-apoptotic action of zinc may also be exerted through effects on caspases [111]. If zinc deficiency does induce apoptosis of $\mathrm{T}$ cells in humans, similarly to findings in cultures of primary human upper airway epithelia [112, 113], this might negatively impact $\mathrm{T}$ cell immunity to pneumonia, which could be reversed with adjunctive zinc therapy.

\section{SUMMARY}

We argue that further mechanistic immunological studies are necessary to optimise the usefulness of any benefits of zinc adjunct therapy for severe pneumonia. Animal studies show that thymic and $\mathrm{T}$ cell development is influenced by zinc, with data emerging from humans; although hypothesisdriven studies are lacking.

The balance of evidence suggests that zinc supplementation reduces the burden of pneumonia in children under the age of 5 years, but inconclusive data begs for more studies to establish its role as adjunctive therapy. Not surprisingly the existing evidence indicates that a greater benefit from zinc may be expected if the subjects are actually zinc deficient. This is difficult to ascertain using blood zinc levels and more suitable biomarkers of body zinc status are needed. The dosage of zinc administered must take into account the bioavailability issues specific to the study populations.

In conclusion, we predict that in the absence of mechanistic studies including the role of zinc in specific immunological pathways such as T cell immunity, it may be impossible to disentangle the full potential of zinc adjunct therapy for pneumonia in children. Understanding specific immunological mechanisms would make it possible to establish markers which would serve as measures to: 1) better target interventions; 2) provide empirical tools to 
monitor treatment and predict prognosis and recurrence; and 3 ) foresee possible long term positive and adverse effects.

\section{ACKNOWLEDGEMENT}

This manuscript is supported by the MRC (UK) Nutrition Programme.

\section{REFERENCES}

[1] Rudan I, Boschi-Pinto C, Biloglav Z, Mulholland K, Campbell H. Epidemiology and etiology of childhood pneumonia. Bull World Health Organ 2008; 86: 408-16.

[2] Caulfield LE, de Onis M, Blossner M, Black RE. Undernutrition as an underlying cause of child deaths associated with diarrhea, pneumonia, malaria, and measles. Am J Clin Nutr 2004; 80:193-8.

[3] Black RE. Zinc deficiency, infectious disease and mortality in the developing world. J Nutr 2003; 133: 1485S-9.

[4] Scott JA, Brooks WA, Peiris JS, Holtzman D, Mulhollan EK. Pneumonia research to reduce childhood mortality in the developing world. J Clin Invest 2008; 118: 1291-300.

[5] Black RE, Morris SS, Bryce J. Where and why are 10 million children dying every year? Lancet 2003; 361: 2226-34.

[6] Garenne M, Ronsmans C, Campbell H. The magnitude of mortality from acute respiratory infections in children under 5 years in developing countries. World Health Stat Q 1992; 45: 180-91.

[7] Mathers C, Stein C, Ma Fat D, et al. Global Burden of Disease 2000: version 2 methods and results. (Internet communication at web site http://search.who.int/search?q=mathers+stein\&btnG=Sear ch\&ie $=$ utf $8 \&$ site $=$ default_collection\&lr $=$ lang_en \&client $=$ WHO\&p roxystylesheet=WHO\&output=xml_no_dtd\&oe=UTF-8\&Search $=$ Search \&sitesearch $=\&$ sort $=$ date $\% 3 \mathrm{AD} \% 3 \mathrm{AL} \% 3 \mathrm{Ad} 1 \&$ entqr $=3 \& \mathrm{u}$ d=1) 2002; Discussion Paper No. 50.

[8] Mulholland K. Childhood pneumonia mortality--a permanent global emergency. Lancet 2007; 370: 285-9.

[9] Mulholland K. Global burden of acute respiratory infections in children: implications for interventions. Pediatr Pulmonol 2003; 36: 469-74.

[10] WHO: The global burden of disease 2004 update. http://www.who. int/healthinfo/global_burden_disease/GBD_report_2004update_full .pdf 2004.

[11] Tapiero H, Tew KD. Trace elements in human physiology and pathology: zinc and metallothioneins. Biomed Pharmacother 2003; 57: 399-411.

[12] Shankar AH, Prasad AS. Zinc and immune function: the biological basis of altered resistance to infection. Am J Clin Nutr 1998; 68: 447S-63S.

[13] Beyersmann D, Haase H. Functions of zinc in signaling, proliferation and differentiation of mammalian cells. Biometals 2001; 14: 331-41

[14] Hershfinkel M, Silverman WF, Sekler I. The zinc sensing receptor, a link between zinc and cell signaling. Mol Med 2007; 13: 331-6.

[15] Bao B, Prasad AS, Beck FW, Sarkar FH. Zinc up-regulates NFkappaB activation via phosphorylation of IkappaB in HUT-78 (Th0) cells. FEBS Lett 2007; 581: 4507-11.

[16] Fraker PJ, King LE. Reprogramming of the immune system during zinc deficiency. Annu Rev Nutr 2004; 24: 277-98.

[17] Strand TA, Aaberge IS, Maage A, Ulvestad E, Sommerfelt H. The immune response to pneumococcal polysaccharide vaccine in zincdepleted mice. Scand J Immunol 2003; 58: 76-80.

[18] Strand TA, Hollingshead SK, Julshamn K, Briles DE, Blomberg B, Sommerfelt H. Effects of zinc deficiency and pneumococcal surface protein a immunization on zinc status and the risk of severe infection in mice. Infect Immun 2003; 71: 2009-13.

[19] FAO. Animal products, richest sources of dietary zinc. www.fao.org/infoods/software/worldfood.html.

[20] IZiNCG. Assessment of the risk of zinc defficiency in populations and options for control. IZiNCG Technical Document 2004; 1: p. 114.

[21] McMahon RJ, Cousins RJ. Mammalian zinc transporters. J Nutr 1998; 128: 667-70.

[22] Swanson CA, King JC. Zinc and pregnancy outcome. Am J Clin Nutr 1987; 46: 763-71.

[23] Miller LV, Hambidge KM, Naake VL, Hong Z, Westcott JL, Fennessey PV. Size of the zinc pools that exchange rapidly with plasma zinc in humans: alternative techniques for measuring and relation to dietary zinc intake. J Nutr 1994; 124: 268-76.

[24] Liuzzi JP, Cousins RJ. Mammalian zinc transporters. Annu Rev Nutr 2004; 24: 151-72.

[25] Brown KH. Effect of infections on plasma zinc concentration and implications for zinc status assessment in low-income countries. Am J Clin Nutr 1998; 68: 425S-9S.

[26] King JC, Shames DM, Woodhouse LR. Zinc homeostasis in humans. J Nutr 2000; 130: 1360S-6S.

[27] Zavaleta N, Lanata C, Butron B, Peerson JM, Brown KH, Lonnerdal B. Effect of acute maternal infection on quantity and composition of breast milk. Am J Clin Nutr 1995; 62: 559-63.

[28] Brown KH, Lanata CF, Yuen ML, Peerson JM, Butron B, Lonnerdal B. Potential magnitude of the misclassification of a population's trace element status due to infection: example from a survey of young Peruvian children. Am J Clin Nutr 1993; 58: 54954 .

[29] Ruz M, Solomons NW, Mejia LA, Chew F. Alteration of circulating micronutrients with overt and occult infections in anaemic Guatemalan preschool children. Int J Food Sci Nutr 1995; 46: $257-65$.

[30] Friis H, Ndhlovu P, Kaondera K, et al. Serum concentration of micronutrients in relation to schistosomiasis and indicators of infection: a cross-sectional study among rural Zimbabwean schoolchildren. Eur J Clin Nutr 1996; 50: 386-91.

[31] Aydemir TB, Blanchard RK, Cousins RJ. Zinc supplementation of young men alters metallothionein, zinc transporter, and cytokine gene expression in leukocyte populations. Proc Natl Acad Sci U S A 2006; 103: 1699-704.

[32] Fischer WCL, Ezzati M, Black RE. Global and regional child mortality and burden of disease attributable to zinc deficiency. Eur J Clin Nutr 2009; 63(5): 591-7.

[33] Golden MH. Proposed recommended nutrient densities for moderately malnourished children. Food Nutr Bull 2009; 30: S267342.

[34] Golden MH. Specific deficiencies versus growth failure: type I and type II nutrients. SCN News 1995; 12: 10-4.

[35] Brown) ITDCHaKH. Assessment of the risk of zinc defficiency in populations and options for control. Food Nutr Bull 2004; 25: S94S204.

[36] Blössner MdOaM. WHO global data base on child growth and malnutrition. WHO Geneva 1997; WHO/NUT/97.4: pp. 1-74.

[37] Bryce J, Boschi-Pinto C, Shibuya K, Black RE: WHO estimates of the causes of death in children. Lancet 2005; 365: 1147-52.

[38] UN. The Millenium Development Goals Report http://www.un. org/millenniumgoals/. 2009.

[39] Ruel MT, Rivera JA, Santizo MC, Lonnerdal B, Brown KH. Impact of zinc supplementation on morbidity from diarrhea and respiratory infections among rural Guatemalan children. Pediatrics 1997 ; 99: 808-13.

[40] Bhandari N, Taneja S, Mazumder S, Bahl R, Fontaine O, Bhan MK: Adding zinc to supplemental iron and folic acid does not affect mortality and severe morbidity in young children. J Nutr 2007; 137: 112-7.

[41] Richard SA, Zavaleta N, Caulfield LE, Black RE, Witzig RS, Shankar AH. Zinc and iron supplementation and malaria, diarrhea, and respiratory infections in children in the Peruvian Amazon. Am J Trop Med Hyg 2006; 75: 126-32.

[42] Rosado JL, Lopez P, Munoz E, Martinez H, Allen LH. Zinc supplementation reduced morbidity, but neither zinc nor iron supplementation affected growth or body composition of Mexican preschoolers. Am J Clin Nutr 1997; 65: 13-9.

[43] Sazawal S, Black RE, Jalla S, Mazumdar S, Sinha A, Bhan MK. Zinc supplementation reduces the incidence of acute lower respiratory infections in infants and preschool children: a doubleblind, controlled trial. Pediatrics 1998; 102: 1-5.

[44] Brooks WA, Santosham M, Naheed A, et al. Effect of weekly zinc supplements on incidence of pneumonia and diarrhoea in children younger than 2 years in an urban, low-income population in Bangladesh: randomised controlled trial. Lancet 2005; 366: 9991004.

[45] Bhandari N, Bahl R, Taneja S, et al. Effect of routine zinc supplementation on pneumonia in children aged 6 months to 3 years: randomised controlled trial in an urban slum. BMJ 2002; 324: 1358. 
[46] Bhutta ZA, Black RE, Brown KH, et al. Prevention of diarrhea and pneumonia by zinc supplementation in children in developing countries: pooled analysis of randomized controlled trials. Zinc Investigators' Collaborative Group. J Pediatr 1999; 135: 689-97.

[47] Aggarwal R, Sentz J, Miller MA. Role of zinc administration in prevention of childhood diarrhea and respiratory illnesses: a metaanalysis. Pediatrics 2007; 119: 1120-30.

[48] Mathew JL. Zinc supplementation for prevention or treatment of childhood pneumonia: a systematic review of randomized controlled trials. Indian Pediatr 2010; 47: 61-66.

[49] Brooks WA, Yunus M, Santosham M, et al. Zinc for severe pneumonia in very young children: double-blind placebo-controlled trial. Lancet 2004; 363: 1683-8.

[50] Mahalanabis D, Chowdhury A, Jana S, et al. Zinc supplementation as adjunct therapy in children with measles accompanied by pneumonia: a double-blind, randomized controlled trial. Am J Clin Nutr 2002; 76: 604-7.

[51] Bose A, Coles CL, Gunavathi, et al. Efficacy of zinc in the treatment of severe pneumonia in hospitalized children $<2 \mathrm{y}$ old. Am J Clin Nutr 2006; 83: 1089-96; quiz 1207.

[52] Valentiner-Branth P, Shrestha PS, Chandyo RK, et al. A randomized controlled trial of the effect of zinc as adjuvant therapy in children 2-35 mo of age with severe or nonsevere pneumonia in Bhaktapur, Nepal. Am J Clin Nutr 2010; 91: 1667-74.

[53] Chang AB, Torzillo PJ, Boyce NC, et al. Zinc and vitamin A supplementation in Indigenous Australian children hospitalised with lower respiratory tract infection: a randomised controlled trial. Med J Aust 2006; 184: 107-12.

[54] Tielsch JM, Khatry SK, Stoltzfus RJ, et al. Effect of daily zinc supplementation on child mortality in southern Nepal: a community-based, cluster randomised, placebo-controlled trial. Lancet 2007; 370: 1230-9.

[55] Sazawal S, Black RE, Ramsan M, et al. Effect of zinc supplementation on mortality in children aged 1-48 months: a community-based randomised placebo-controlled trial. Lancet 2007; 369: 927-34.

[56] Brooks WA, Santosham M, Roy SK, et al. Efficacy of zinc in young infants with acute watery diarrhea. Am J Clin Nutr 2005; 82: 605-10.

[57] Iqbal AS, Shahidullah M, Islam MN, Akhter S, Banu S. Serum zinc and copper levels in the maternal blood and cord blood of neonates. Indian J Pediatr 2001; 68: 523-6.

[58] Muller $\mathrm{O}$, Becher $\mathrm{H}$, van Zweeden $\mathrm{AB}$, et al. Effect of zinc supplementation on malaria and other causes of morbidity in west African children: randomised double blind placebo controlled trial. BMJ 2001; 322: 1567

[59] Sazawal S, Black RE, Menon VP, et al. Zinc supplementation in infants born small for gestational age reduces mortality: a prospective, randomized, controlled trial. Pediatrics 2001; 108: 1280-6.

[60] Howie S, Zaman SM, Omoruyi O, Adegbola R, Prentice A. Severe pneumonia research and the problem of case definition: the example of zinc trials. Am J Clin Nutr 2007; 85: 242-3; author reply 243 .

[61] Baum MK, Campa A, Lai S, Lai H, Page JB. Zinc status in human immunodeficiency virus type 1 infection and illicit drug use. Clin Infect Dis 2003; 37(Suppl 2): S117-23.

[62] Moore JB, Blanchard RK, Cousins RJ. Dietary zinc modulates gene expression in murine thymus: results from a comprehensive differential display screening. Proc Natl Acad Sci USA 2003; 100: 3883-8.

[63] Fraker PJ, Gershwin ME, Good RA, Prasad A. Interrelationships between zinc and immune function. Fed Proc 1986; 45: 1474-9.

[64] King LE, Frentzel JW, Mann JJ, Fraker PJ. Chronic zinc deficiency in mice disrupted $\mathrm{T}$ cell lymphopoiesis and erythropoiesis while B cell lymphopoiesis and myelopoiesis were maintained. J Am Coll Nutr 2005; 24: 494-502.

[65] Chevalier P, Sevilla R, Zalles L, et al. [Immuno-nutritional recovery of children with severe malnutrition]. Sante 1996; 6: 2018 .

[66] Chevalier P, Sevilla R, Sejas E, Zalles L, Belmonte G, Parent G. Immune recovery of malnourished children takes longer than nutritional recovery: implications for treatment and discharge. $\mathrm{J}$ Trop Pediatr 1998; 44: 304-7.

[67] Blackburn CC, Manley NR. Developing a new paradigm for thymus organogenesis. Nat Rev Immunol 2004; 4: 278-89.
[68] Collinson AC, Moore SE, Cole TJ, Prentice AM. Birth season and environmental influences on patterns of thymic growth in rural Gambian infants. Acta Paediatr 2003; 92: 1014-20.

[69] Pilch SM, Senti FR. Analysis of zinc data from the second National Health and Nutrition Examination Survey (NHANES II). J Nutr 1985; 115: 1393-7.

[70] Aaby P, Marx C, Trautner S, et al. Thymus size at birth is associated with infant mortality: a community study from GuineaBissau. Acta Paediatr 2002; 91: 698-703.

[71] Garly ML, Trautner SL, Marx C, et al. Thymus size at 6 months of age and subsequent child mortality. J Pediatr 2008; 153: 683-8.

[72] Golden MH, Jackson AA, Golden BE. Effect of zinc on thymus of recently malnourished children. Lancet 1977; 2: 1057-9.

[73] Gastinel LN, Dardenne M, Pleau JM, Bach JF. Studies on the zinc binding site to the serum thymic factor. Biochim Biophys Acta 1984; 797: 147-55

[74] Prasad AS, Meftah S, Abdallah J, et al. Serum thymulin in human zinc deficiency. J Clin Invest 1988; 82: 1202-10.

[75] Dardenne M, Pleau JM. Interactions between zinc and thymulin. Met Based Drugs 1994; 1: 233-9.

[76] Gastinel LN, Pleau JM, Dardenne M, et al. High affinity binding sites on plasma membrane obtained from the lymphoblastoid cultured 1301 cell line for highly radioactive serum thymic factor. Biochim Biophys Acta 1982; 684: 117-26.

[77] Dardenne M, Pleau JM, Nabarra B, et al. Contribution of zinc and other metals to the biological activity of the serum thymic factor. Proc Natl Acad Sci U S A 1982; 79: 5370-3.

[78] Seki T, Spurr N, Obata F, Goyert S, Goodfellow P, Silver J. The human Thy-1 gene: structure and chromosomal location. Proc Natl Acad Sci U S A 1985; 82: 6657-61.

[79] Haeryfar SM, Hoskin DW. Thy-1: more than a mouse pan-T cell marker. J Immunol 2004; 173: 3581-8.

[80] Prasad AS. Clinical, immunological, anti-inflammatory and antioxidant roles of zinc. Exp Gerontol 2008; 43: 370-7.

[81] Humbert M, Monti G, Brenot F, et al. Increased interleukin-1 and interleukin-6 serum concentrations in severe primary pulmonary hypertension. Am J Respir Crit Care Med 1995; 151: 1628-31.

[82] Simonneau G, Galie N, Rubin LJ, et al. Clinical classification of pulmonary hypertension. J Am Coll Cardiol 2004; 43: 5S-12S.

[83] Henriques-Coelho T, Oliveira SM, Moura RS, et al. Thymulin inhibits monocrotaline-induced pulmonary hypertension modulating interleukin-6 expression and suppressing p38 pathway. Endocrinology 2008; 149: 4367-73.

[84] Yara S, Kawakami K, Kudeken N, et al. FTS reduces bleomycininduced cytokine and chemokine production and inhibits pulmonary fibrosis in mice. Clin Exp Immunol 2001; 124: 77-85.

[85] Haddad JJ, Land SC, Saade NE, Safieh-Garabedian B. Immunomodulatory potential of thymulin- $\mathrm{Zn}(2+)$ in the alveolar epithelium: amelioration of endotoxin-induced cytokine release and partial amplification of a cytoprotective IL-10-sensitive pathway. Biochem Biophys Res Commun 2000; 274: 500-5.

[86] Reggiani PC, Herenu CB, Rimoldi OJ, et al. Gene therapy for longterm restoration of circulating thymulin in thymectomized mice and rats. Gene Ther 2006; 13: 1214-21.

[87] Tuomanen EI, Austrian R, Masure HR. Pathogenesis of pneumococcal infection. N Engl J Med 1995; 332: 1280-4.

[88] Blue CE, Paterson GK, Kerr AR, Berge M, Claverys JP, Mitchell TJ. ZmpB, a novel virulence factor of Streptococcus pneumoniae that induces tumor necrosis factor alpha production in the respiratory tract. Infect Immun 2003; 71: 4925-35.

[89] Ohbayashi H. Matrix metalloproteinases in lung diseases. Curr Protein Pept Sci 2002; 3: 409-21.

[90] Fraker PJ, Haas SM, Luecke RW. Effect of zinc deficiency on the immune response of the young adult A/J mouse. J Nutr 1977; 107: 1889-95.

[91] Liuzzi JP, Lichten LA, Rivera S, et al. Interleukin-6 regulates the zinc transporter Zip14 in liver and contributes to the hypozincemia of the acute-phase response. Proc Natl Acad Sci U S A 2005; 102: 6843-8.

[92] Greenberger PA. 7. Immunologic lung disease. J Allergy Clin Immunol 2008; 121: S393-7; quiz S418.

[93] Fehervari Z, Sakaguchi S. CD4+ Tregs and immune control. J Clin Invest 2004; 114: 1209-17.

[94] Coutinho A, Caramalho I, Seixas E, Demengeot J. Thymic commitment of regulatory $\mathrm{T}$ cells is a pathway of TCR-dependent 
selection that isolates repertoires undergoing positive or negative selection. Curr Top Microbiol Immunol 2005; 293: 43-71.

[95] Pillai V, Karandikar NJ. Human regulatory T cells: a unique, stable thymic subset or a reversible peripheral state of differentiation? Immunol Lett 2007; 114: 9-15.

[96] Lang C, Murgia C, Leong M, et al. Anti-inflammatory effects of zinc and alterations in zinc transporter mRNA in mouse models of allergic inflammation. Am J Physiol Lung Cell Mol Physiol 2007; 292: L577-84

[97] Siewert E, Dietrich CG, Lammert F, et al. Interleukin-6 regulates hepatic transporters during acute-phase response. Biochem Biophys Res Commun 2004; 322: 232-8.

[98] Nemeth E, Tuttle MS, Powelson J, et al. Hepcidin regulates cellular iron efflux by binding to ferroportin and inducing its internalization. Science 2004; 306: 2090-3.

[99] Aggarwal BB, Shishodia S, Ashikawa K, Bharti AC. The role of TNF and its family members in inflammation and cancer: lessons from gene deletion. Curr Drug Targets Inflamm Allergy 2002; 1: $327-41$.

[100] Prasad AS. Clinical, immunological, anti-inflammatory and antioxidant roles of zinc. Exp Gerontol 2008; 43(50): 370-7.

[101] Krezel A, Maret W. Different redox states of metallothionein/ thionein in biological tissue. Biochem J 2007; 402: 551-8.

[102] Bray TM, Bettger WJ. The physiological role of zinc as an antioxidant. Free Radic Biol Med 1990; 8: 281-91.

[103] Prasad AS, Bao B, Beck FW, Kucuk O, Sarkar FH. Antioxidant effect of zinc in humans. Free Radic Biol Med 2004; 37: 1182-90.

[104] Bettger WJ, O'Dell BL. A critical physiological role of zinc in the structure and function of biomembranes. Life Sci 1981; 28: 142538.
[105] Sempertegui F, Diaz M, Mejia R, et al. Low concentrations of zinc in gastric mucosa are associated with increased severity of Helicobacter pylori-induced inflammation. Helicobacter 2007; 12: 43-8.

[106] Perrone GG, Tan SX, Dawes IW. Reactive oxygen species and yeast apoptosis. Biochim Biophys Acta 2008; 1783(7): 1354-68.

[107] Wang L, Azad N, Kongkaneramit L, et al. The Fas death signaling pathway connecting reactive oxygen species generation and FLICE inhibitory protein down-regulation. J Immunol 2008; 180: 3072-80.

[108] Fukamachi Y, Karasaki Y, Sugiura T, et al. Zinc suppresses apoptosis of U937 cells induced by hydrogen peroxide through an increase of the Bcl-2/Bax ratio. Biochem Biophys Res Commun 1998; 246: 364-9.

[109] King LE, Osati-Ashtiani F, Fraker PJ. Apoptosis plays a distinct role in the loss of precursor lymphocytes during zinc deficiency in mice. J Nutr 2002; 132: 974-9.

[110] Akita K, Okamura H, Yoshida K, Morimoto H, Ogawa-Iyehara H, Haneji T. Cobalt chloride induces apoptosis and zinc chloride suppresses cobalt-induced apoptosis by Bcl-2 expression in human submandibular gland HSG cells. Int J Oncol 2007; 31: 923-9.

[111] Truong-Tran AQ, Ho LH, Chai F, Zalewski PD. Cellular zinc fluxes and the regulation of apoptosis/gene-directed cell death. J Nutr 2000; 130: 1459S-66S.

[112] Bao S, Knoell DL. Zinc modulates cytokine-induced lung epithelial cell barrier permeability. Am J Physiol Lung Cell Mol Physiol 2006; 291: L1132-41.

[113] Bao S, Knoell DL. Zinc modulates airway epithelium susceptibility to death receptor-mediated apoptosis. Am J Physiol Lung Cell Mol Physiol 2006; 290: L433-41.

This is an open access article licensed under the terms of the Creative Commons Attribution Non-Commercial License (http://creativecommons.org/licenses/by$\mathrm{nc} / 3.0 /$ ) which permits unrestricted, non-commercial use, distribution and reproduction in any medium, provided the work is properly cited. 